\title{
Defining space
}

Devotees of television's long-running Star Trek odysseys know that space is the final frontier. While architects may not have much to do with outer space, interior space and the spaces between buildings are generally considered our stock-in-trade. And the notion of space has been invoked frequently in twentieth-and twenty-first century polemics claiming new architectural frontiers. Avant gardes from early Moderns to advocates of digital design have sought to claim the invention of radical new kinds of space. In less strident terms, qualities of space are also invoked by architectural critics - on television, radio and in the press - in their judgements of quality in architecture (to return to the theme of arq $11 / 3+4$ ). Yet we suspect that few contemporary critics or architects would claim more than a loose understanding of the ideas bound up in the concept of space.

Following a historical survey of the word's usage, Adrian Forty suggests in his book Words and Buildings that architects and others tend to confuse two different appreciations of space: as a mental concept for understanding the world; and as a 'thing' which architects can manipulate. ${ }^{1}$ Such confusions were the motivation for a conference held at University College Dublin in September 2007, several papers from which appear in this issue of arq. As Mari Hvattum suggests in her conference review (pp. 206-208), the event did not so much outline new frontiers in the conception of space as survey existing ones. Unsurprisingly, despite the optimism of the conference title, no singular definition of space - old or new emerged. However the discussions, which are sampled here, offered important insights for both practitioners and academics in their review of this central but neglected topic.

Peter Mörtenböck and Helga Mooshammer explore processes of trade, dispersal and re-aggregation in informal markets (pp. 347-357). Nishat Awan theorises the role of a Shaheed Minar sited in an East London park and its role in the life of local communities in order to raise possibilities for postcolonial space (pp. 263-268). Ben Stringer and Jane McAllister, through a series of polemical drawings mixing images from air travel and the domestic realm, ask provocative questions about globalised space (pp. 249-254). Christopher Pierce looks at how Diller, Scofidio + Renfro manage the representation of built and un-built spaces in their work. Drawing is also the method by which Claus Peder Pedersen addresses questions of ambiguity in digital design (pp. 223-230).

Space is always constrained by the vicissitudes of culture, practice and technology. Acknowledging this, contributions from beyond the conference included here address the role of regulations in determining design (pp. 213-215), the value of architectural research to society (pp. 216-222), and environmental conditions in the Crystal Palace (pp. 283-294).

While the invention of new forms of space may remain beyond architects' grasp, revisiting conceptions of space and exploring new ways of thinking about it will always remain fruitful pursuits. They may lack the glamour of outer space and its beguiling fictions, but they nevertheless have plenty to offer for the design of our more earth-bound environments.

THE EDITORS 


\section{architectural research quarterly}

\section{Subscribe now for 2009}

Innovative in conception, unique in breadth and generously illustrated, this pace-setting quarterly publication from Cambridge University Press links, on a global scale, the worlds of architectural practice and research. arq regularly includes extensive peer-reviewed sections on design, history, theory, construction, environmental design, information technology and practice - as well as structures, urbanism and documents. These are supplemented by letters, reports, reviews, a directory of specialist research centers and consultancies and an annual index. Each issue opens with a leader and closes with insight, a personal end-piece. In its ten year history, arq has published work from all over the world: from Chile to Sweden and from Japan to the Netherlands - with a strong representation from the United Kingdom and United States. arq, like architecture itself, is all-embracing and written by and for both practitioners and academics. It provides an outlet for all those who wish to disseminate their work to an international audience.
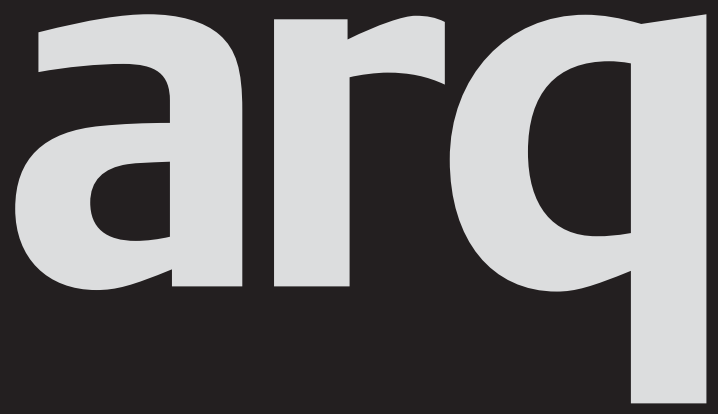

Please enter my subscription to arq: architectural research quarterly, volume 13, 2009 $\square$ E186/\$308 institutions print and electronic $\square E_{30} / \$ 50$ students print only

$\square$ £42/\$64 individuals print only

EU residents only. VAT may be payable at your local rate if not registered.

Our VAT registration number: GB 214141614 If registered, your VAT registration no:

Total subscription payment $£ / \$$ EU residents only, if not registered add VAT at appropriate rate

Canadian residents, add 7\% GST \$

Name

Total $\mathbf{E} / \mathbf{\$}$

Address

Payment enclosed

Cheque in sterling or US dollars

(payable to Cambridge University Press)

Credit Card - VISA | MasterCard | American Express (delete where applicable)

Card no

Expiry date

Signature

Photocopy this page and send your order to:

Journals Customer Services, Cambridge University Press, The Edinburgh Building, Cambridge, CB2 8RU, UK

T $+44(0) 1223326070$

$\mathrm{F}+44(0) 1223315052$

E journals@cambridge.org

or in USA, Canada and Mexico send to:

Cambridge University Press, 32 Avenue of the

Americas, New York NY 10013-2473, USA

T (914) 9379600

F (914) 9374712

E journals_subscriptions@cup.org 